\title{
Harmonia axyridis (Pallas, 1773) (Coleoptera: Coccinellidae) - expansion to the north: first records of invasion species in Yaroslavl and Novgorod Regions
}

\author{
Alexey S. Sazhnev ${ }^{1 *} \oplus$, Dmitry V. Vlasov², Aleksander A. \\ Rusinov ${ }^{3}$, Viktor D. Titov ${ }^{4}$
}

\begin{abstract}
1 I.D. Papanin Institute for Biology of Inland Waters, Russian Academy of Sciences, Borok 109, Nekouz District, Yaroslavl Region, 152742 Russia

${ }^{2}$ The Yaroslavl museum preserve, Bogoyavlenskaya ploshchad 25, Yaroslavl, Yaroslavl Region, 150000 Russia

${ }^{3}$ P.G. Demidov Yaroslavl State University, ul. Sovetskaya 14, Yaroslavl, Yaroslavl Region, 150003 Russia

${ }^{4}$ Administration of the Rostov District of Yaroslavl Region, Sovetskaya ploshchad 15, Yaroslavl Region, Rostov, 152151 Russia

*sazh@list.ru
\end{abstract}

Received: 06.09.2021

Revised: 20.10.2021

Accepted: 21.10 .2021

Published online: 16.11.2021

DOI: $10.23859 /$ estr-210906

UDC 574.43; 595.76

Translated by S.V. Nikolaeva
Abstract. The paper gives information on the invasion of Harmonia axyridis (Pallas, 1773) (Coleoptera: Coccinellidae) into the north of the European part of Russia. The Asian ladybird is recorded for the first time from the Novgorod and Yaroslavl Regions. All records of this alien species from European Russia and the Northern Caucasus are listed.

Keywords: invasion, Asian ladybird, alien species, fauna, beetles.

To cite this article. Sazhnev, A.S. et al., 2021. Harmonia axyridis (Pallas, 1773) (Coleoptera: Coccinellidae) - expansion to the north: first records of invasion species in Yaroslavl and Novgorod Regions. Ecosystem Transformation 4 (4), 3-6. https://doi.org/10.23859/estr210906

\section{Introduction}

The Asian ladybird, or harlequin ladybird Harmonia axyridis (Pallas, 1773) (Coleoptera: Coccinellidae) (Fig. 1), which has a native range in northeastern Kazakhstan, China, Mongolia, Korea, Japan and the Asian regions of Russia (South Siberia and the Far East, including its insular part) (Andrianov et al., 2018), has recently been actively spreading within the European part of Russia, which to a large extent poses a risk for native species of Coccinellidae.

In European Russia, Harmonia axyridis was first discovered in 2004 in the Belgorod Region (Orlova-
Bienkowskaja, 2013), then this species was recorded in a number of regions of the European part of Russia from Kaliningrad and Moscow to the southern regions of the Chernozem Region and the republics of the Caucasus (Orlova-Bienkowskaja, 2013, 2014), and in recent years (2018-2020) has quickly spread across the the Volga Region and the center of European Russia (Egorov et al., 2019; Ruchin et al., 2020; Sazhnev et al., 2020). Judging by the findings, the distribution of Harmonia axyridis goes from south to north (donor regions, probably the Krasnodar Region and the Caucasus) and from west to east, i.e., from the European countries bordering Russia, where the 
species was introduced back in the early 2000 s and spread widely (Roy et al., 2016).

\section{Materials and methods}

On the territory of the Yaroslavl Region, the alien species Harmonia axyridis was first discovered in 2020. During expeditionary studies in 2021 in different areas of the Yaroslavl Region, the authors also collected last instar (L4) larvae preparing for pupation, pupae and adults. In total, more than 70 specimens were collected. The material is kept in the collection of the Institute of Biology of Inland Waters (IBIW RAS, collections of A.S. Sazhnev), the Zoological Museum Yaroslavl State University named after P.G. Demidov (ZMYarSU, collections of A.A. Rusinov), private collections of D.V. Vlasov (CV) and V.D. Titov (CT). The data for the Novgorod region were kindly provided by colleagues. Some of the distribution points were obtained thanks to the "iNaturalist" project (https://www.inaturalist.org/).

\section{Material:}

Novgorod Region: Veliky Novgorod, 08.08.2021, larva L4 (1 specimen), E. Chausova (photo).

Yaroslavl region: Rostov, center, Sovetskaya ploshad, 23.09.2020, imago f. succinea (1 specimen), CT; in the same place, ul. Marshala Alekseeva, 23.08.2021, adult f. succinea (1 specimen), CT; the same place, 08.09.2021, imago f. succinea (3 specimens), CT; the same place, 13.09.2021, imago f. spectabilis (1 specimen), CT.

Rostov District, village Spirtsovo, on leaves of white dogwood (Cornus alba Linnaeus, 1767), 19.09.2021, pupa (3 specimens), growing to imago f. succinea 24.09.2021 (1 specimen) and 26.09.2021 (1 specimen), CT.
Nekouz District, Borok village, 28.07.2021, larva L4 (1 specimen), IBIW RAS; the same place, 30.07.2021, pupa (1 specimen), imago f. succinea (19 specimens), IBIW RAS; the same place, 02.08.2021, L4 larva (2 specimens), pupa (1 specimen), imago f. succinea (15 specimens), IBIW RAS; the same place, 03.08.2021, imago f. succinea (1 specimen), IBIW RAS; the same place, 14.08.2021, imago f. succinea (1 specimen), IBIW RAS; the same place, 22.08.2021, imago f. succinea (1 specimen), IBIW RAS.

Yaroslavl, Zavolzhsky District, entering apartment on the 5th floor, 15.08.2021, imago f. succinea (1 specimen), ZMYarSU; Yaroslavl, Dzerzhinsky District, on poplar bushes, 19.08.2021, adult f. succinea (1 specimen), CV; the same place, trunk of linden, 14.09.2021, larva L4 (1 specimen), pupa (2 specimens taken for hatching, f. succinea emerged, 24.09.2012, CV); Yaroslavl, Kirovsky District, 12.09.2021, larva L4 (1 specimen), pupa (1 specimen), A. Stolbovsky (photo); the same place, 24.09.2021, on Sedum flowers, imago f. succinea (1 specimen), CV; Yaroslavl, on the walls of buildings and on a fence on the Volga and Kotorosl river embankment, 06-16.10.2021, imago, (> 20 specimens), CV.

Pereslavl District, vicinity of village of Glebovskoe, on ruderal grasses, 10.08.2021, imago f. succinea (7 specimens), CV; Pereslavl-Zalessky, on a pine, imago f. spectabilis, 24.08.2021 (1 specimen), A.D. Gorbunov (photo).

Most of the adults collected during the study were assigned to the color form $\mathrm{f}$. succinea; f. spectabilis was recorded in Pereslavl-Zalessky, in Rostov and the village of Spirtsovo (Rostov district). Mass pupa-
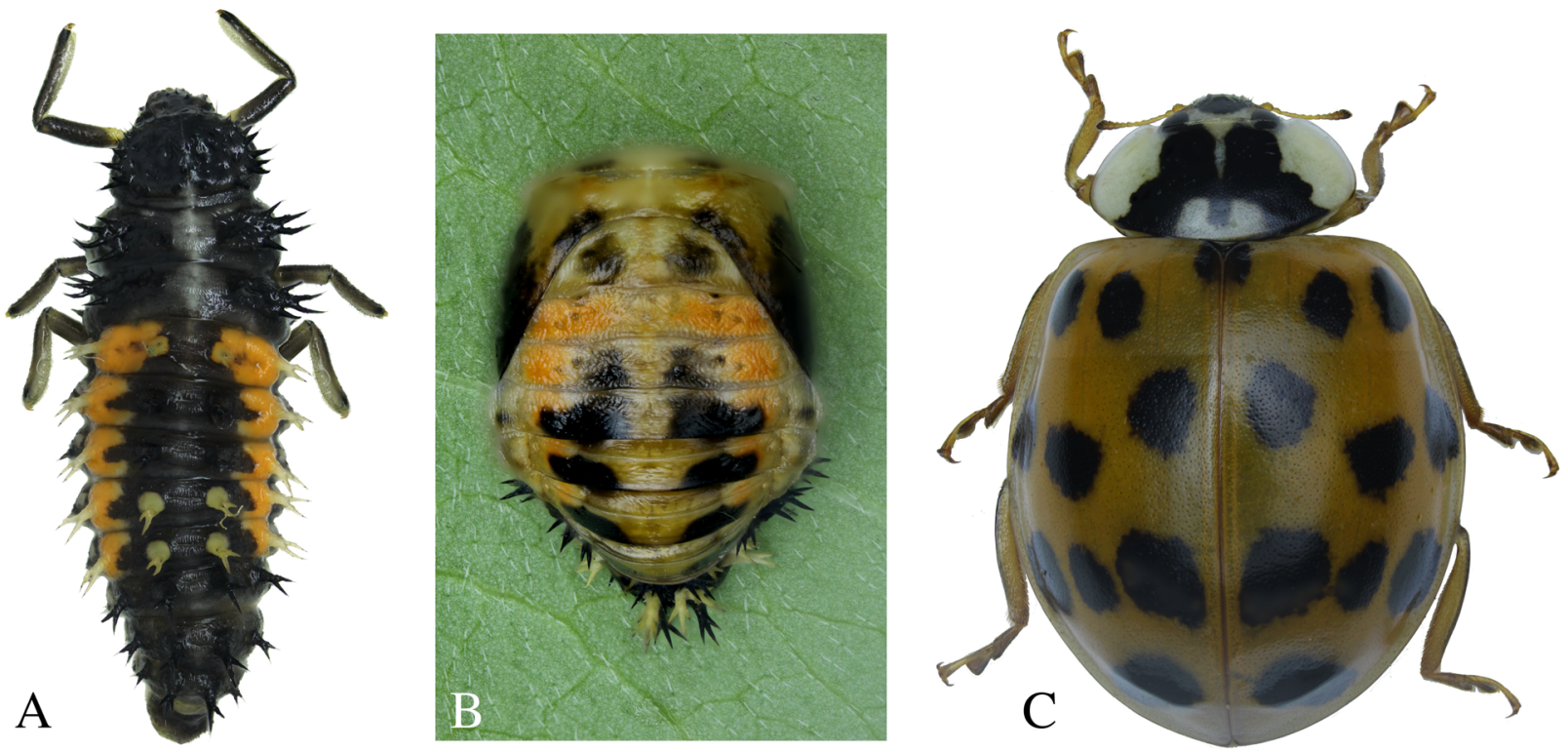

Fig. 1. Harmonia axyridis (Yaroslavl Region, Borok village). A - larva L4, B - pupa, C - adult f. succinea (photographs by A.S. Sazhnev). 


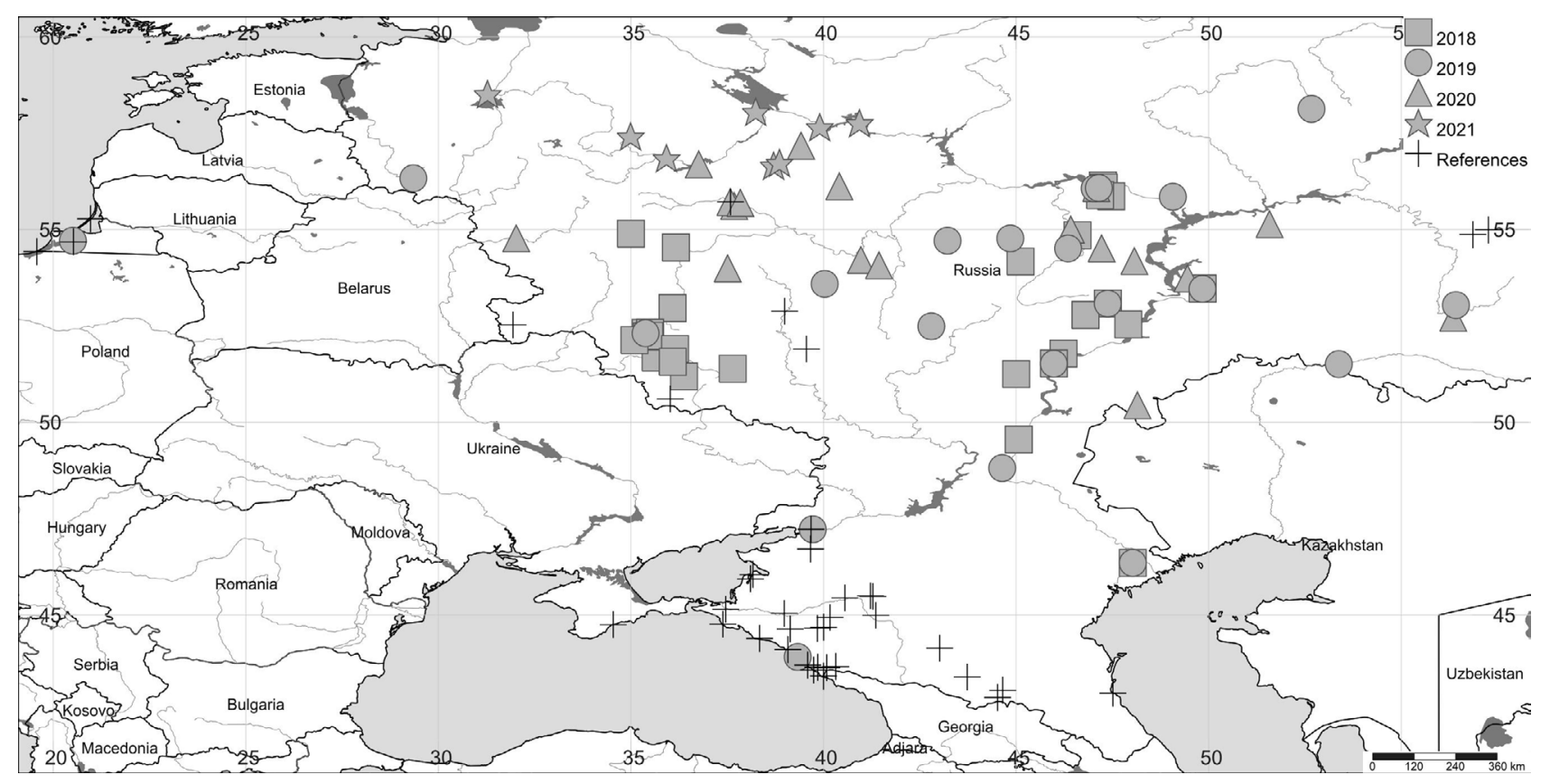

Fig. 2. The modern range of Harmonia axyridis in European Russia and the Northern Caucasus (all points on map (except references) author's data)

tion of larvae was observed in early to mid-August (August 02-14, 2021) in Borka and in the first ten days of September (09.09.2021) in Rostov.

\section{Results and discussion}

At present, the record of the Asian ladybird Harmonia axyridis in the Novgorod and Yaroslavl regions (as well as the record from the city of Glazov, Udmurt Republic (Sazhnev et al., 2020)) are the northernmost sites for the secondary range of this invasive species within European Russia. Most likely, the distribution of the species to the north will extend beyond these records, and records of the ladybird can be expected in adjoining northern regions, such as the Pskov, Vologda, Leningrad regions, the Republic of Karelia, etc. For instance, at present Harmonia axyridis is known in the Baltic Region and Scandinavia: Latvia, Estonia and Finland (Barševskis, 2009; Kallavus, 2018; pers. data).

Undoubtedly, the expansion of many species outside their ranges has an anthropogenic basis. However, modern global processes of climate change contribute to the extension and change of ranges: in particular, an increase in average annual temperatures allows certain species shift their distribution northwards. For Harmonia axyridis, the question of the limit of its range and the possibility of successfully overwintering in the northern part remains open, since even in more southern regions, a rather large percentage of individuals of this species died during overwintering (Sazhnev et al., 2020).

\section{Conclusions}

Thus, according to the literature (Ruchin et al., 2020; Sazhnev et al., 2020) and our own observations, the modern range of Harmonia axyridis in European Russia and the North Caucasus covers the following regions (Fig. 2): Astrakhan, Belgorod, Bryansk, Vladimir, Volgograd, Voronezh, Kaliningrad, Kaluga, Kostroma, Lipetsk, Moscow, Nizhny Novgorod, Novgorod, Orenburg, Oryol, Penza, Pskov, Rostov, Ryazan, Samara, Saratov, Tula, Ulyanovsk and Yaroslavl regions, city of Moscow, Krasnodar, Stavropol, the Republic of Adygea, Bashkiria, Dagestan, Kabardino-Balkaria, KarachayCherkessia, Crimea, Mordovia, North Ossetia-Alania, Tatarstan, Udmurt, Chechen and Chuvashia regions.

\section{Funding}

The work of A.S. Sazhnev was carried out within the framework of the state assignment of the Ministry of Science and Higher Education of the Russian Federation no. 121051100109-1.

\section{ORCID}

A.S. Sazhnev (D) $\underline{0000-0002-0907-5194}$

\section{References}

Andrianov, B.V., Blechman, A.V., Goryacheva, I.I., Zakharov-Gezekhus, I.A., Romanov, D.A., 2018. Aziatskaya bozh'ya korovka Harmonia axyridis: global'naya invaziya [Asian ladybug Harmonia axyridis: a global invasion]. KMK, Moscow, Russia, 143 p. (In Russian). 
Barševskis, A., 2009. Multicoloured Asian lady beetle (Harmonia axyridis (Pallas, 1773)) (Coleoptera: Coccinellidae) for the first time in the fauna of Latvia. Baltic Journal of Coleopterology 9, 135-138.

Egorov, L.V., Podshivalina, V.N., Borisova, N.V., Ruchin, A.B., 2019. Harmonia axyridis (Pallas, 1773) (Coleoptera: Coccinellidae) - novyi chuzherodnyi vid $v$ faune Povolzh'ya [Harmonia axyridis (Pallas, 1773) (Coleoptera: Coccinellidae) a new alien species for the Volga region fauna]. Eversmannia 59-60, 73. (In Russian).

Kallavus, T., 2018. Aasia lepatriinu (Harmonia axyridis) - levik ja tõrjevõimalused. Bachelor's degree thesis. Tartu, Estonia, 47 p. (In Estonian).

Orlova-Bienkowskaja, M.Ja., 2013. The dangerous invasive harlequin ladybird Harmonia axyridis (Pallas, 1773) (Coleoptera, Coccinellidae) in European Russia. Russian Journal of Biological Invasions 4 (3), 190-193. https://www.doi. org/10.1134/S2075111713030107

Orlova-Bienkowskaja, M.Ja., 2014. The outbreak of harlequin ladybird Harmonia axyridis (Pallas, 1773)
(Coleoptera, Coccinellidae) in the Caucasus and possible sources of invasion. Russian Journal of Biological Invasions 5 (4), 275-281. https://www. doi.org/10.1134/S2075111714040055

Roy, H.E., Brown, P.M.J., Adriaens, T., Berkvens, N., Borges, I. et al., 2018. The harlequin ladybird, Harmonia axyridis: global perspectives on invasion history and ecology. Biological Invasions 18, 9971044. http://www.doi.org/10.1007/s10530-016$1077-6$

Ruchin, A.B., Egorov, L.V., Lobachev, E.A., Lukiyanov, S.V., Sazhnev, A.S., Semishin, G.B., 2020. Expansion of Harmonia axyridis (Pallas, 1773) (Coleoptera: Coccinellidae) to European part of Russia in 2018-2020. Baltic Journal of Coleopterology 20 (1), 51-60.

Sazhnev, A.S., Anikin, V.V., Zolotukhin, V.V., 2020. Overwintering and new records of invasive harlequin ladybird Harmonia axyridis (Pallas, 1773) (Coleoptera: Coccinellidae) after mass expansion to European part of Russia in 2018-2019. Russian Journal of Ecosystem Ecology 5 (4), 1-6. http:// www.doi.org/10.21685/2500-0578-2020-4-4 